\title{
SEVERAL FACTORS THAT AFFECT CATTLE ROWING PATTERNS AS WELL AS THEIR CONTRIBUTION TO HOUSEHOLD INCOME (CASE STUDY OF LIVESTOCK FARMERS IN TAEBENU SUBDISTRICT, KUPANG REGENCY, NTT)
}

\author{
Salden E. Nifu ${ }^{1 *}$, Djoko Koestiono ${ }^{2}$, Hery Toiba ${ }^{2}$ \\ ${ }^{1}$ Master of Agribusiness Study Program, Faculty of Agriculture, Brawijaya University, Indonesia \\ ${ }^{2}$ Faculty of Agriculture, Brawijaya University, Indonesia \\ *corresponding author: saldennifu@gmail.com
}

\begin{abstract}
This study aims to analyze several factors that affect cattle rowing patterns as well as their costs, receipts and contributions to the household income of livestock farmers in Taebenu Subdistrict, Kupang Regency, NTT. The research sample of 100 people was grouped into two groups: group I (50 row cattle farmers) and group II (50 non-row cattle farmers). Determination of the number of farmer samples follows slovin formula with random sampling method. Data on factors that influence the decisions of farmers' households are analyzed with binary logistics regression analysis. Meanwhile, the income of cattle farmers and non-rowdy cattle was analyzed by household income analysis. The results showed that the analysis of binary logistics regression using simultaneous tests showed that independent variables (X) namely $\mathrm{X}_{1}, \mathrm{X}_{2}, \mathrm{X}_{3}, \mathrm{X}_{4}, \mathrm{X}_{5}, \mathrm{X}_{6}$ significantly influenced dependent variables (Y). The

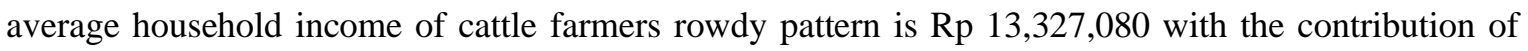
income from the business of cattle rowing by $21.93 \%$, while the average household income of non-rowdy cattle farmers (privately owned) Rp 12,820,488 with the contribution of income from non-row cattle businesses amounted to $22.93 \%$. From the results of household income shows the household income of cattle farmers row pattern higher than the household income of non-row cattle farmers (privately owned).
\end{abstract}

Keywords: Cattle Business Rowdy and Non Rowdy, Household Income, Influence Factors.

http://dx.doi.org/10.21776/ub.agrise.2021.021.3.2

Received 12 April 2021

Accepted 7 July 2021

Available online 31 July 2021

\section{INTRODUCTION}

Sub-sectors of animal husbandry in economic development may play a role in several things, among others: (a) Supporting economic growth (has contributed to GDP), (b) National employment providers, (c) Sources of income, (d) Providers of animal protein needs, (e) Foreign exchange producers, (f) Drivers of industrial sector growth (Hartono, 2011). The role of the livestock sub-sector is increasingly important and strategic in line with indications of increased demand and per capita consumption of various livestock products. A significant increase in demand is thought to be due to increasing population, increased per capita income, changes in people's tastes, and the development of industrial numbers and scale.

Sutawi (2012) in Nalle (2017) stated that the combination of increased income, population growth and per capita consumption will drive the increasing demand for farm products at a rapid pace. Trantono, (2009) stated one of the efforts made by the government to increase contributions, functions and roles in the region, namely to 
conduct cattle partnerships with farming communities in the form of rowdy patterns. The desire to partner arises from each party that does not own cattle. The establishment of agribusiness partnerships is a business relationship between the core and plasma where each party earns income from interconnected business ventures with the aim of achieving mutual profit based on mutual need and mutual benefit although it can also occur, that the partnership arises due to the role of third parties.

Partnership with the pattern of beef cattle rowing conducted in Taebenu Subdistrict, Kupang Regency, namely the farming community as plasma and the Village Government as a stakehoder conduct mutually beneficial relations through legal relations conducted based on the signing of a contract for the brewing of beef cattle (Balinese cattle). The contract period of cattle cattle brewing lasts for two years with one of the agreements, namely stakeholders give one bull to each Plasma (farmer) and the farmer will refund the initial price of cattle purchase to the government after the cattle are sold.

Efforts to develop beef cattle by farmers require a briefing of various capabilities to utilize existing production functions with the aim of increasing farmers' incomes. In the livestock business can be done business analysis in order to know the receipts, production costs and income from livestock business. In addition, it is necessary to analyze factors that affect the household income of rowdy and non-rowdy cattle farmers in order to maximize the household income of farmers.

This paper raises the issue of factors that influence the decision of household cattle farmers to follow the rowdy and do not follow the row and how much the cost, receipt and net income obtained by the households of cattle farmers rowdy and non-rowdy patterns. The purpose of this study is to analyze the factors that influence the decision of cattle farmers to follow the row and not follow the row and the amount of costs, receipts and contributions to the household income of livestock farmers in Taebenu Subdistrict, Kupang Regency, East Nusa Tenggara Province (NTT).

\section{RESEARCH METHODS \\ Research Sites And Resonden Samples}

This research was conducted in Taebenu Subdistrict, Kupang Regency, East Nusa Tenggara Province, Indonesia. The research time took place in October-November 2020. Samples of livestock farmers are taken using simple random sampling method based on rowdy cattle farmers and nonrowdy cattle farmers (privately owned). The number of cattle farmers sampled amounted to 100 divided into two groups, namely group I: 50 row cattle farmers and group II: 50 non-row cattle farmers. The calculation of the respondent's sample using slovin formula (Nasution and Syahbudin 2014) namely $n=N /(N . d . d+1)$ where $n$ = sample size, $\mathrm{N}=$ population size, $\mathrm{d}=$ guessing error $(10 \%)$.

\section{Data Analysis Techniques}

The data obtained from the interview results of respondents in the field are processed and tabulated. Then the data is analyzed using income analysis method and logistic regression analysis which is processed with econometric approach model and explained descriptively.

Net income from pig breeding activities, can be calculated by formula (Hartono, 2010):

Where:

$\boldsymbol{\pi}=$ Total income or profit earned from cattle farmers (Rp/year).

$\mathrm{TR}=$ Total revenue or revenue obtained by cattle farmers (Rp/year).

$\mathrm{TC}=$ Total cost incurred by cattle farmers (Rp/year).

Contribution of income of Bali cattle business rowing patterns and non-rowing patterns to the household income of farmers can be calculated using the equation (Satria in Gusti, et al. 2013):

$$
K=\frac{Y 1}{Y \text { total }} \times 100 \%
$$

Where:

$\mathrm{K}=$ Contribution of cattle business to the household income of farmers $(\%)$

$\mathrm{Y} 1=$ Cattle business income $(\mathrm{Rp} / \mathrm{Year})$

Based on the data obtained in the study, so to analyze the factors that influence the decision of the household of cattle farmers to follow the rowdy and the decision of the household of cattle farmers not to follow the row (private property) can be analyzed using the Econometric Approach Model using analysis of Binary Logistics Regression using small STATA 14.2 tools. Binary 
Logistics Regression Model is used to analyze the relationship between one response variable (dependent) and several predictor variables (independent), with the response variable in the form of qualitative data dichotomy that is worth 1 to state the decision of the farmer for gaduhan and worth 0 to state the decision of the farmer not to be rowdy (private property). In this study used the formula in general analysis of binary logistics regression to find out the characteristic factors of farmers that influence the household decisions of cattle farmers for rowdy and household decisions of cattle farmers not to be rowdy (Santoso, 2001).

$\left.\log \mid \frac{\operatorname{Pr} o b \text { (Event) }}{\operatorname{Pr} o b \text { (Non Event })}\right\rceil=\beta_{0}+\beta_{1} X_{1}+\cdots+\beta_{k} X_{k}$

Furthermore, the general formula of binary logistics regression analysis applied in this study to measure the influence of independent variables (free variables) $\mathrm{X}$ against dependent variables (Bound variables) Y can be used rumur as follows: $\log \left(\frac{\text { Prob (Decision of the Row pattern) }}{\text { Prob (Decisions are not the Row pattern) }}\right)=\beta_{0}+\beta_{1} X_{1}+\beta_{2} X_{2}+\beta_{3} X_{3}+\beta_{4} X_{4}+\beta_{5} X_{5}+\beta_{6} X_{6}$

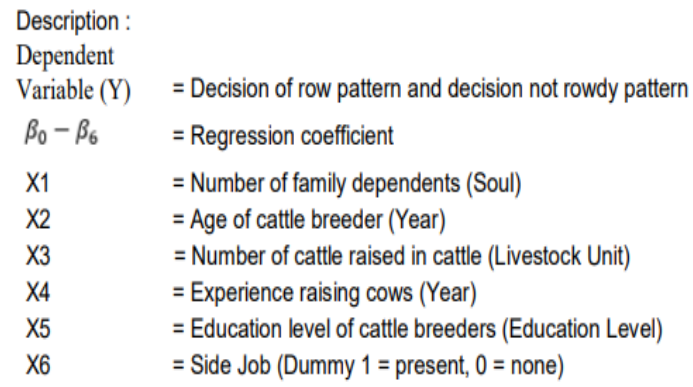

\section{RESULTS AND DISCUSSION}

Analysis of several factors that affect the pattern of cattle rowing in Taebenu Subdistrict, Kupang Regency, NTT Province.

\section{Binary Logistics Regression Analysis}

In this study, simultaneous tests were measured by showing that the LR value of chisquare (31.91) with a p-value of $(0.000)<=0.05$ (5\%) which means $\mathrm{H} 1$ is accepted or can be said that at a significance level of 5\%, there is sufficient evidence that independent variables $(\mathrm{X})$ are the number of family dependents $\left(\mathrm{X}_{1}\right)$, the age of cattle breeders $\left(\mathrm{X}_{2}\right)$, the number of cattle raised $\left(X_{3}\right)$, the experience of raising cattle $\left(X_{4}\right)$, the level of education of cattle breeders $\left(\mathrm{X}_{5}\right)$, side jobs $\left(\mathrm{X}_{6}\right)$ which statistically significantly affect dependent variables (Y) (household decisions of livestock farmers to follow the row and household decisions of farmers not to follow the row (private property). As for seeing how much an independent variable (X) can explain its effect on dependent variables (Y) it can be measured using the Pseudo R-Square test. Where the value of Pseudo R-Square in this study is (23.02). It can be said that in this study, the ability of independent variables (X) can explain the diversity of dependent variable data (Y) by $23.02 \%$ while the rest is explained by other variables outside the model that are not shaved in this study.

Based on the coefficient of parameters on the output in this study, it can be described the following binary logistics regression model:

$\left.g(x)=\log \mid \frac{\pi(x)}{1-\pi(x)}\right)=0,0543-0,0811 x_{1}+0,0499 X_{2}+0,1550 X_{3}+0,0831 X_{4}+0,0055 X_{5}-1,1350 X_{6}$

Source: Processed from primary data, 2020.

\section{Partial Hypothesis Test}

In this study to see the partial influence of independent variables (free variables) on dependent variables (bound variables) then it was done by looking, if the $\mathrm{p}$-value value < a significant level $a=0.05(5 \%)$ then it can be said to accept $\mathrm{H}_{1}$ and reject $\mathrm{H}_{0}$ or in other words that an independent variable (X) partially affects dependent variables (Y). The presentation of logistic regression data from the results of this study can be seen in Table 1. as follows.

Table 1. The result of a pasrial (individually) logistic regression of free variables.

\begin{tabular}{|c|c|c|c|c|c|c|}
\hline$Y$ & Odds Ratio & Std. Err. & 2 & $P>|z|$ & 1958 Conf. & Interval] \\
\hline $\mathrm{X} 1$ & .9220159 & .1423487 & $-0,53$ & 0.599 & .6812753 & 1.247826 \\
\hline$x 2$ & 1.051219 & .026881 & 1.95 & 0.051 & .9998315 & 1.105247 \\
\hline$\times 3$ & 1.167689 & .1065893 & 1.70 & 0.089 & .9763999 & 1.396455 \\
\hline$X 4$ & 9201801 & .0170684 & $-4,48$ & 0.000 & .8873275 & .9542491 \\
\hline X5 & 1.005585 & .1096939 & 0.05 & 0.959 & .8120182 & 1.245294 \\
\hline 86 & .3214112 & .4873872 & $-0,75$ & 0.454 & .0164551 & 6.277995 \\
\hline- cons & .9471115 & 2.20882 & $=0.02$ & 0.981 & .0098007 & 91.52571 \\
\hline
\end{tabular}

Source: Processed from primary data, 2020.

Based on the data in Table 3.1 above if seen in the $p$-value indicates that the results of a partial analysis of logistic regression of independent variables $(\mathrm{X})$ on variable $\mathrm{X}_{4}$ (experience breeding cows) statistically show a significant influence or $\mathrm{p}$-value $<\mathrm{a}=0.05(5 \%)$ dependent variables (Y) (the decision of the 
household of cattle farmers to follow the row and the decision of the household of cattle farmers not to follow the row). While in the independent variable $X_{1}$ (number of family dependents), $\left(X_{2}\right)$ the age of cattle breeders, $\left(X_{3}\right)$ the number of cattle raised, $\left(\mathrm{X}_{5}\right)$ the level of education of cattle breeders and $\left(\mathrm{X}_{6}\right)$ side jobs, statistically shows an insignificant influence or $\mathrm{p}$-value of $>\mathrm{a}=0.05$ (5\%) dependent variables (Y) (the decision of the household of cattle farmers to follow the row and the decision of the household of cattle farmers not to follow the row). This shows that the experience of raising cattle $\left(\mathrm{X}_{4}\right)$ contributes significantly to the decision of the household of cattle farmers to follow the row and the decision of the household of cattle farmers not to follow the rowdy. While the number of family dependents $\left(X_{1}\right)$, the age of cattle farmers $\left(X_{2}\right)$, the number of cattle raised $\left(\mathrm{X}_{3}\right)$, the level of education of cattle farmers $\left(\mathrm{X}_{5}\right)$, side jobs $\left(\mathrm{X}_{6}\right)$ do not contribute significantly to the decision of the household cattle farmers to follow the row and the decision of the household of cattle farmers not to follow the gaduhan (private property).

The following partial hypothesis test of logistic regression can be interpreted based on the Odds ratio value of an independent variable (X) against a dependent variable (Y) which can be described as follows:

The effect of the variable number of family dependents $\left(X_{1}\right)$ on the variable decision of the farmer's household to follow the rowdy and not follow the rowdy (Y)

The average number of family dependents from the households of cattle farmers and non-rowing cattle breeders in Taebenu Subdistrict is 5 people per Family Head (KK) with specifications in one family - an average of 1 to 3 people in the family members are undergoing education ranging from elementary, junior high, high school to college (PT). The more family members in the household will affect the burden borne by the farmer's household.

The results of the partial hypothesis test obtained showed that the variable number of family dependents $\left(X_{1}\right)$ statistically had no significant effect on the decision of the households of cattle farmers to follow the row and the decision of the households of cattle farmers not to follow the row (private property) in Taebenu Subdistrict.
This is evidenced by the results of the analysis of logistic regression obtained p-value of 0.599 while the significant level of $a=0.05(5 \%)$ which proves that the p-value of $0.599>0.05$ (significance). Therefore, the hypothesis obtained from this study is $\mathrm{H}_{0}$ received and $\mathrm{H}_{1}$ rejected which means that the variable number of family dependents $\left(\mathrm{X}_{1}\right)$ is insignificant to the decision of the household of cattle farmers to follow the row and the decision of the household of cattle farmers not to follow the rowdy (private property).

The number of family dependents is insignificant to the decision of the household of cattle farmers to follow the row and the decision of the household of cattle farmers not to follow the row (private property) in Taebenu Subdistrict due to the educational factors undertaken by family members and environmental and cultural factors of NTT provincial community in general and the people of Kupang Regency in particular. The high cost of spending on the number of family dependents caused by cultural factors, namely the hajatan event of religious parties and cultural rituals (family gatherings) that require each family member to contribute to the cultural customs caused by the people of Kupang Regency in general and the people of Taebenu Subdistrict in particular still highly uphold the local wisdom that traditionally interacts socially in the community. This is supported by the results of Tukan research (2019) which states that the number of family dependents affects the households of farmers due to educational, environmental and cultural factors of ntt provincial community in general that upholds local wisdom in the form of hajatan events, religious rituals and customary rituals that are always carried out by the community so as to further increase the needs of farmers households that can increase the number of family dependents increased.

\section{Effect of cattle breeder's age variable $\left(X_{2}\right)$ on the variable of the household decision of the cattle farmer to follow the rowdy and not follow the rowdy (Y)}

The results of partial hypothesis testing obtained show that the variable age of cattle farmers $\left(\mathrm{X}_{2}\right)$ statistically has no significant effect on the decision of the households of cattle farmers to follow the row and the decision of the households of cattle farmers not to follow the row 
(private property) in Taebenu Subdistrict. This is evidenced by the results of the analysis of logistic regression obtained p-value of 0.051 while the significant level of $a=0.05(5 \%)$ which proves that the p-value of $0.051>0.05$ (significance). Therefore, the hypothesis obtained from this study is $\mathrm{H}_{0}$ accepted and $\mathrm{H}_{1}$ rejected which means that the variable age of cattle farmers $\left(\mathrm{X}_{2}\right)$ is insignificant to the decision of household cattle farmers to follow the row and the decision of the household cattle farmers not to follow the rowdy (private property).

In the business of cattle rowing patterns and non-rowing cattle business (privately owned) average - the average cattle farmer has an age ranging from 20 years to 55 years that is still classified as the productive age of cattle farmers in the research area. Ownership of cattle in large numbers requires good physical ability of farmers in order to run livestock businesses. Especially in the feed management section of the research site, farmers must take animal feed in cattle every day with a distance of approximately $1-2 \mathrm{~km}$ which is reached by foot and feed will be brought to the livestock pen by carrying feed on the shoulders of livestock. This is the consideration that if the ownership of livestock is getting more and more then the age of cattle farmers should be more productive. According to Urmanto (2014) states that in general young farmers have better physical abilities when compared to farmers who have an older age. Age differences usually contribute differently to responses to technology and science. In addition, age can also affect the success of business because age plays an important role in productivity, memory, courage to take risks and mindset in accepting innovation.

The variable effect of the number of cattle raised $\left(X_{3}\right)$ on the household decision variables of cattle farmers to follow the rowdy and not follow the rowdy (Y)

The average number of cattle ownership in the research area ranges from $1-3.50$ units of cattle (UT). This causes the people of Taebenu Subdistrict to make cattle business a leading commodity in the field of animal husbandry after the community's leading commodity in agriculture, namely corn, vegetables, cassava, coconut, cashews in increasing the household income of cattle farmers rowdy patterns and household income of non-rowing cattle farmers (privately owned). According to Lalus (2018) stated that the maintenance of cattle in Kupang Regency on a scale of $1-5$ units of livestock ownership (ST) has been better than the larger scale of livestock ownership, although maintenance management is still far to be said commercially.

The results of the partial hypothesis test obtained show that the variable number of cattle maintained $\left(\mathrm{X}_{3}\right)$ has no statistically significant effect on the decision of the households of cattle farmers to follow the row and the decision of the households of cattle farmers not to follow the row (private property) in Taebenu Subdistrict. This is evidenced by the results of the analysis of logistic regression obtained $\mathrm{p}$-value of 0.089 while the significant level of $a=0.05(5 \%)$ proving that the p-value of $0.089>0.05$ (significance). Therefore, the hypothesis obtained from this study is $\mathrm{H}_{0}$ accepted and $\mathrm{H}_{1}$ rejected which means that the variable number of cattle maintained $\left(\mathrm{X}_{3}\right)$ is insignificant to the household decision of cattle farmers to follow the row and the decision of the household of cattle farmers not to follow the rowdy (private property).

In the maintenance of cattle non rowdy patterns in the research area also makes farmers not to sell livestock if there is no urgent need in large quantities. It is also supported by the customs and culture of the community that requires to pay belis (dowry) if you want to marry a woman using cattle and also for weddings and religious events require to provide beef as a food menu. According to Lalus (2018) which states that if reviewed from social needs then the ownership of cattle is as a show of prestige from the owner. While judging from the economic needs, the ownership of cattle is as a savings to overcome various urgent needs of tunia money in large quantities, then cattle is the solution or in other words the maintenance of cattle is intended as a precautionary measure guard in the face of urgent needs.

The variable influence of cattle breeding experience $\left(\mathrm{X}_{4}\right)$ on the household decision of cattle farmers to follow the row and not follow the rowdy (Y)

The results of partial hypothesis testing obtained show that the variable experience of raising cattle $\left(\mathrm{X}_{4}\right)$ statistically has a significant 
effect on the decision of the households of cattle farmers to follow the row and the decision of the households of cattle farmers not to follow the row (private property) in Taebenu Subdistrict. This is evidenced by the results of the analysis of logistic regression obtained p-value of 0.000 while the significant level of $a=0.05(5 \%)$ which proves that the p-value of $0.000<0.05$ (significance). Therefore, the hypothesis obtained from this study is $\mathrm{H}_{1}$ accepted and $\mathrm{H}_{0}$ rejected which means that the variable experience of raising cattle $\left(\mathrm{X}_{4}\right)$ has a significant effect on the decision of the household of cattle farmers to follow the row and the decision of the household of cattle farmers not to follow the rowdy (private property).

If the experience is getting longer than a cattle farmer, it will affect the decision of the household to follow the business of rowdy cattle and not follow the business of rowdy cattle. The experience of raising cows is identical to the long maintenance of cattle both in the business of rowing patterns and personal cattle business. The longer cattle are kept due to the maintenance system that is still traditional by utilizing animal feed from feed land, grazing fields without diversification of good feed with high quality to be able to increase the Weight Gain Agency (PBB) of livestock quickly so that cattle are quickly sold. Because the longer the livestock is raised, the greater the costs incurred and the profit obtained will be less. According to Lalus (2018) stated that the length of maintenance of livestock is related to the cost of production, where the shorter the time it takes in the maintenance of a cattle to reach the selling weight, the better because the acceptance of farmers will be greater. While if the time it takes a cattle to achieve a longer selling weight, it will cause the cost of production to be greater and subsequently cause the income to be smaller.

Effect of Variable level of education of cattle farmers $\left(\mathrm{X}_{5}\right)$ on the variable of household decisions of cattle farmers to follow the rowdy and not follow the rowdy (Y)

In general, the level of education of farmers in Taebenu Subdistrict, Kupang regency is still relatively low because the average level of education of farmers is at the highest $60 \%$ only elementary school graduates. This leads to limited ability in managing cattle business rowing patterns and non-rowing cattle business (private property).
The results of the partial hypothesis test obtained show that the variable level of education of cattle farmers $\left(\mathrm{X}_{5}\right)$ has statistically no significant effect on the decision of the households of cattle farmers to follow the row and the decision of the households of cattle farmers not to follow the row (private property) in Taebenu Subdistrict. This is evidenced by the results of the analysis of logistic regression obtained p-value of 0.959 while the significant level of $a=0.05(5 \%)$ which proves that the p-value of $0.959>0.05$ (significance). Therefore, the hypothesis obtained from this study is $\mathrm{H}_{0}$ accepted and $\mathrm{H}_{1}$ rejected which means that the variable level of education of cattle farmers $\left(\mathrm{X}_{5}\right)$ is insignificant to the decision of the household of cattle farmers to follow the rowdy and the decision of the household of cattle farmers not to follow the rowdy (private property).

If the education level of cattle farmers is getting better then it will further improve the insight of a farmer in implementing new innovations in the maintenance process and can support the acceleration of the increase in the weight of livestock bodies (PBB) so that cattle are quickly sold and efforts continue to run to the maximum and continue to increase the income of farmers. According to Soekartawi in Tukan (2019) stated that the low education of workers is an obstacle in absorbing new information, especially related to the process of diffusion - technological innovation. According to Tukan (2019) stated that the limitations of education owned by farmers are not a benchmark in breeding because with sufficient experience and supported by non-formal education in the field of agriculture and livestock makes livestock farmers able to develop agricultural businesses and livestock in general.

Effect of side job variables $\left(X_{6}\right)$ on the variables of the decision of the household of cattle farmers to follow the rowdy and not follow the rowdy $(Y)$

The results of the partial hypothesis test obtained show that the variable side work $\left(\mathrm{X}_{6}\right)$ has no statistically significant effect on the decision of the households of cattle farmers to follow the row and the decision of the households of cattle farmers not to follow the row (private property) in Taebenu Subdistrict. This is evidenced by the results of the analysis of logistic regression obtained p-value of 0.454 while the significant 
level of $a=0.05(5 \%)$ proving that the $p$-value of $0.454>0.05$ (significance). Therefore, the hypothesis obtained from this study is $\mathrm{H}_{0}$ accepted and $\mathrm{H}_{1}$ rejected which means that the variable of side work $\left(\mathrm{X}_{6}\right)$ is insignificant to the decision of the household of cattle farmers to follow the rowdy and the decision of the household of cattle farmers not to follow the rowdy (private property).

The decision of farmers in Taebenu Subdistrict to run non-cattle businesses in order to increase the contribution of household income of farmers from non-cattle businesses in addition to cattle businesses, farming businesses and also non-agricultural businesses run. Farming and nonagricultural businesses such as carpentry, trade run by domestic farmers livestock farmers are also only household scale with consideration only to increase the household income of farmers but not used as the main business. On the other hand, more and more diversification of business in the household of farmers will be able to allocate working time from members of the farmer's household if the number of productive workers in the household in large numbers.

According to Zahri and Febriansyah in Nazir et al, (2015) stated that farmers develop business diversification to face the risks and uncertainties of income from the farm run. Business diversification activities conducted by farmer households lead to the development of various business patterns developed by farmers' households. In addition, the development of business diversification is carried out when income from farming activities is insufficient for farmers' household needs throughout the year.

\section{Cost Analysis, Revenue and Contribution to The Household Income of Livestock Farmers in Taebenu Subdistrict, Kupang Regency.}

Household net income of cattle farmers rowdy and non-rowing patterns (private property) is the difference between household receipts and household expenditures of cattle farmers rowdy patterns and non-rowing patterns. The total household revenue includes cattle business income and non-rowing patterns, non-business income of cattle, non-livestock farming income and non-farm income in farmer's household. In the households of cattle farmers rowdy patterns and non-rowing patterns there are production costs that are inseparable from the business run by the farmer's household. Production costs incurred by the households of cattle farmers are production costs incurred by farmers as an investment.

Table 2. Average - Average Production Cost of Cattle Cattle Business Row pattern and Non Rowing Pattern in Research Area (Rp/Respondent/Year), Year 2020.

\begin{tabular}{|c|c|c|c|c|c|}
\hline \multirow[t]{2}{*}{ No } & \multirow[t]{2}{*}{ Production Cost Components } & \multicolumn{2}{|c|}{$\begin{array}{l}\text { Cattle Business Row } \\
\text { Pattern }\end{array}$} & \multicolumn{2}{|c|}{$\begin{array}{l}\text { Non-Rowing Cattle } \\
\text { Business (OWn) }\end{array}$} \\
\hline & & $\mathrm{RP}$ & $\%$ & $\mathrm{Rp}$ & $\%$ \\
\hline \multirow[t]{7}{*}{1} & Variable Costs & & & & \\
\hline & Livestock Purchase & 5.621 .100 & 88,40 & 4.851 .465 & 85,18 \\
\hline & Feed Costs & 150.000 & 2,36 & 168.750 & 2,96 \\
\hline & Cost of Medicines & 34.815 & 0,55 & 46.750 & 0,82 \\
\hline & Injection Fee & 54.792 & 0,86 & 43.293 & 0,76 \\
\hline & Water Cost & 21.429 & 0,34 & 23.571 & 0,41 \\
\hline & Total Variable Costs & 5.882 .135 & 92,51 & 5.133 .829 & 90,14 \\
\hline \multirow[t]{15}{*}{2} & Fixed cost & & & & \\
\hline & Feed and Drink Place & 24.700 & 0,39 & 32.417 & 0,57 \\
\hline & Plastic buckets & 40.000 & 0,63 & 36.241 & 0,64 \\
\hline & Broom & 10.000 & 0,16 & 11.933 & 0,21 \\
\hline & Shovel & 69.211 & 1,09 & 66.944 & 1,18 \\
\hline & Hoe & 20.000 & 0,31 & 66.136 & 1,16 \\
\hline & Machete & 35.000 & 0,55 & 76.111 & 1,34 \\
\hline & Tova & 15.000 & 0,24 & 43.200 & 0.76 \\
\hline & Celurt & 40.000 & 0,63 & 49.600 & 0,87 \\
\hline & Sprayer & 42.490 & 0,67 & 44.537 & 0.78 \\
\hline & Rope & 50.000 & 0,79 & 40.958 & 0,72 \\
\hline & Cost of Making Cages & 100.000 & 1,57 & 73.485 & 1,29 \\
\hline & Cost of Cage Renovation & 30.000 & 0.47 & 20.000 & 0,35 \\
\hline & Total Fixed Cost & 476.401 & 7,49 & 561.564 & 9,86 \\
\hline & Total Production Costs & 6.358 .536 & 100,00 & 5.695 .393 & 100,00 \\
\hline
\end{tabular}

Source: Processed from primary data, 2020.

Of the total production costs, feed costs are also costs incurred by household cattle farmers row pattern and also household cattle farmers non row pattern (privately owned). However, the cost of feed issued by domestic cattle farmers rowing patterns and non-rowing patterns is a type of transpotasi cost for the transportation of large amounts of feed such as rice straw and corn straw from farmland owned by livestock farmers. This is done by farmers when the availability of animal feed conditions begin to decrease, farmers must transport feed from farmland owned by farmers to be able to support the need for cattle feed.

In this study there is no cost incurred by farmers for the purchase of feed because cattle farmers rowdy patterns and non-rowing patterns have their own animal feed land. According to Lalus (2018) stated that in the maintenance of beef cattle in kupang regency, the feed given to livestock is not purchased, because animal feed is taken from farmers' farms. The feed given to livestock is lamtoro, grasses, rice straw, corn straw and other forage that can be eaten by cattle.

According to Rahayu (2013) net income is the difference between the receipt of livestock business per year and the total cost of production 
per year. The calculation of net income is inseparable from the capital spent to run a business because the capital issued in the form of investment will affect the scale of the business that has a direct impact on income. The breakdown of average receipts, expenditures, and net income of cattle farmers' households and non-row patterns in the research area can be seen in Table 3 as follows.

Table 3. Average Revenue, Expenditure (Cost) and Household Net Income of Bali
Cattle Farmers Rowdy and Non-Rowing Patterns in research areas
(Rp/Respondents/Year), Year 2020.

Source: Processed from primary data, 2020.

The data in Table 3.3 above shows that the average household receipt of cattle farmers row pattern is $\operatorname{Rp} 21,221,880 /$ respondent/year. Meanwhile, expenditures incurred by cattle farmers of rowing patterns from businesses run by household farmers amounted to $\mathrm{Rp}$ $7,894,800 /$ respondent/year. From the average receipt and expenditure of households of cattle farmers row pattern, net income was obtained at Rp 13,327,080/respondent/year. Meanwhile, the data received by non-rowing cattle farmers households amounted to $\mathrm{Rp}$ $21,913,600 /$ respondent/year and expenditures issued by non-rowing cattle farmers households for all types of farmer household businesses amounted to Rp 9,093,112/respondent/year. From the data of receipts and expenditures from the households of non-rowed cattle farmers, net

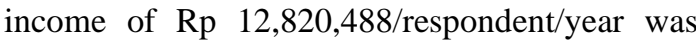
obtained.

Cattle business income row pattern is more oriented towards fattening (male) with a period of livestock maintenance at the fastest one year and a maximum of two years. So that the profit from cattle farmers rowdy pattern faster than non-rowed cattle farmers. While in non-rowing cattle business (privately owned) more oriented in the business that is used as a long-term savings where cattle will be sold at any time if the farmer has a large number of needs. The increase in the net income of cattle farmers' households is due to the contribution of income from cattle businesses and non-rowing patterns that can increase the household income of farmers.
Contribution of Cattle Business Income row pattern and Non Row pattern to household income of farmers in Taebenu subdistrict.

Members of the farmer's household do a type of work is to earn income in order to meet the needs of his household life. The collection of income from various sources is the total income of the household. These diverse sources of income can occur because household members who work, do more than one type of activity or each household member has different activities from each other (Hartono in Tukan, 2019). Household income of cattle farmers rowdy patterns and nonrowing patterns in the research area has the main sources of income from cattle business rowing patterns and non-rowing cattle business (privately owned), non-cattle business, non cattle farming, non-farming. The breakdown of average and percentage of income sources of cattle farmers rowing patterns and non-row patterns can be seen in Table 4 as follows.

\begin{tabular}{lllll}
$\begin{array}{l}\text { Table } \\
\text { 4. Breakdown of Average and Percentage of Income Sources of Cattle Farmers } \\
\text { Row pattern, Non Rowing Pattern in the Research Area (Rp/ Year / } \\
\text { Respondent), Year 2020. }\end{array}$ & $\begin{array}{c}\text { Row pattern cattle } \\
\text { breeders }\end{array}$ & $\begin{array}{c}\text { Non-Row pattern } \\
\text { cattle breeders }\end{array}$ \\
\cline { 2 - 6 } & $\begin{array}{c}\text { Amount } \\
\text { Source of Income }\end{array}$ & $\%$ & $\begin{array}{c}\text { Amount } \\
\text { (Rp) }\end{array}$ & $\%$ \\
\hline $\begin{array}{l}\text { Cattle Business Row Pattern / Non Rowing } \\
\text { Pattern }\end{array}$ & 2.922 .900 & 21,93 & 2.848 .535 & 22,22 \\
Non Business Cattle & 10.404 .180 & 78,07 & 9.971 .953 & 77,78 \\
\hline & 13.327 .080 & 100,00 & 12.820 .488 & 100,00 \\
\hline
\end{tabular}

Source: Processed from primary data, 2020.

The data in Table 3.4 above shows that the average household income of cattle farmers in the rowing pattern sourced from cattle business rowing patterns amounted to $\mathrm{Rp} 2,922,900$ (21.93\%), and that was sourced from non-business cattle cattle amounted to Rp 10,404,180 (78.07\%). The data in the table above shows that cattle businesses are rowing patterns contributing income to the households of row cattle farmers amounting to $21.93 \%$ of the total household income of row cattle farmers. Meanwhile, the average household income of non-rowing cattle farmers (privately owned) was derived from nonrowing cattle businesses amounting to $\mathrm{Rp}$ $2,848,535(22.22 \%)$, and those sourced from nonbusiness cattle cattle amounting to $\mathrm{Rp} 9,971,953$ $(77.78 \%)$. From the above shows that non-rowing cattle business (privately owned) contributes income of $22.22 \%$ of the total household income of non-rowed cattle farmers (privately owned). 
If seen from the household income data of farmers then the total household income of cattle farmers row pattern Rp $13,327,080 /$ respondent/year. This income is greater than the total household income of nonrow cattle farmers Rp $12,820,488 /$ respondent/year. If seen from the percentage then the percentage of household income of cattle farmers row pattern of $50.97 \%$ greater than the percentage of household income of non-row cattle farmers is $49.03 \%$. Household income of cattle farmers rowdy pattern is greater than the household income of non-rowed cattle farmers because in the maintenance of cattle rowdy pattern, farmers only maintain one type of cattle that is fattening males. So that the entire focus of maintenance from farmers ranging from feed management, health is well considered so that the weight gain of livestock is increasing and quickly sold.

While in the maintenance of cattle non rowdy pattern (private property) is also more oriented as long-term savings and also to produce livestock seedlings and will be for the continuation of the business. This is what makes non-rowed cattle farmers in the research area do not make sales in the last 3 years. According to Lalus (2018) who said that the ownership of cattle in Kupang Regency if reviewed in social terms, then the ownership of cattle is a show of prestige from the owner. As for economic needs, as a savings to overcome the urgent need for large amounts of cash, cattle is the solution or in other words the maintenance of cattle is intended as an action to guard - take care in the face of urgent needs. In addition, the maintenance of cattle is also intended to produce their own livestock seedlings and livestock will be for the continuation of business.

\section{CONCLUSION}

a. In binary logistics regression analysis using simultaneous tests showed that the LR chisquare value (31.91) with a p-value was $(0.000)<a=0.05(5 \%)$ which means at a significance level of $5 \%$, there is sufficient evidence that independent variables $(\mathrm{X})$ such as the number of family dependents $\left(X_{1}\right)$, the age of cattle breeders $\left(\mathrm{X}_{2}\right)$, the number of cattle raised $\left(\mathrm{X}_{3}\right)$, the experience of raising cattle $\left(\mathrm{X}_{4}\right)$, the level of education of cattle farmers $\left(\mathrm{X}_{5}\right)$, non-business income of cattle cattle $\left(\mathrm{X}_{6}\right)$, statistically significantly affect dependent variables (Y) i.e. the decision of the household of cattle farmers to follow the row and the decision of the cattle breeders households not to follow the pattern of brewing.

b. The average household income of cattle

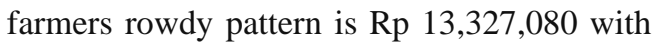
the contribution of income from the business of cattle rowing by $21.93 \%$, while the average household income of non-rowdy cattle farmers (privately owned) $\mathrm{Rp} 12,820,488$ with the contribution of income from non-row cattle businesses amounted to $22.93 \%$. From the results of household income shows the household income of cattle farmers row pattern higher than the household income of non-row cattle farmers (privately owned).

\section{ADVICE}

a. For the government can increase the capacity of cattle business capital row pattern at the village level through village funds so that farmers who have never had the opportunity to raise cattle rowdy pattern, can be given cattle row to be maintained and this rowing program is expected to be rolled out again continuously.

b. The need to improve non-formal education in the form of counseling that is more focused on cattle farmers rowdy patterns and non-rowing cattle farmers so that livestock farmers who still lack experience and knowledge about good livestock maintenance management, in order to be applied to the business carried out.

\section{BIBLIOGRAPHY}

Gusti, P., Jafrinur, and Nofialdi. 2013. Contribution of Beef Cattle Business Income in The Bachelor Program of Village Building (SMD) to The Household Income of Farmers in South Coastal District. "Journal of populist agribusiness", Vol. 3 No. 1: 57 - 63. November 2013.

Hartono, B. 2010. Efforts to Improve the Economy of Dairy Farmers Households, First Printing, April. Publisher UB Pres. Malang.

Lalus, M.F., 2018. Analysis of Beef Cattle Market Integration in Kupang Regency, East Nusa Tenggara Province. Dissertation. Postgraduate Program, Doctoral Program of Livestock Science Faculty of Animal 
Husbandry. University of Brawijaya, Malang.

Nalle, A.A. 2017. Analysis of Domestic Resources by Type of Cattle Cattle In The Upper Watershed Of Benain-Noelmina, West Timor, East Nusa Tenggara. Dissertation. Postgraduate Program, Doctoral Program of Livestock Science Faculty of Animal Husbandry. University of Brawijaya, Malang.

Nasution, Erwin, and Syahbudin. 2014. "Analysis of Coffee Marketing in Humbang Hasundutan Regency, North Sumatra Province." Agrica (North Sumatra Agribusiness Journal) 7 No 1:40-50.

Nazir, I. Zahri, A. Mulyana and Yunita. (2015). Business Patterns and Household Income of Farmers in Various Typology of Rawa Lebak Land. Journal of Management \&Agribusiness, Vol. 12 No. 3, November 2015. E-ISSN: 2407-2524.

Rahayu, E.T. 2013. Analysis of Dairy Cattle Business Revenue in Cepogo Subdistrict, Boyolali Regency. Department of Animal Husbandry, Faculty of Agriculture UNS.
Journal of Animal Husbandry Science Vol. 11 (2). ISSN 1693-8828.

Santoso, S. 2001. SPSS Parametric Statistics. PT Elex Media Komputindo, Jakarta.

Trantono, Y., 2009 Livestock-Online, Business Partnership / Trading / Marketing / Supplier / Supplier of Beef Cattle, Goats and Sheep in partnership with Farmers Farmers Directly, as well as the Company, Articles Division Marketing Cattle Agung Jaya Group.

Tukan, H. D. 2019. Economic Income Analysis of Pig Farm Households in East Flores Regency, East Nusa Tenggara Province. Thesis. Postgraduate Program, Master Program of Livestock Science Faculty of Animal Husbandry. University of Brawijaya, Malang.

Urmunanto. 2014. Analysis of Beef Cattle Business With Partnership Pattern Between Investors (Financiers) With Farmers Farmers (Penggaduh) In The Village Sail District Tenayan Raya Pekanbaru City. Majoring in Agribusiness, Faculty of Agriculture, Riau University. Jom Faperta Vol. (1) No. (2). 